\title{
Metode Biblioterapi dan Diskusi Dilema Moral untuk Pengembangan Karakter Tanggungjawab
}

\author{
Noviana Dewi ${ }^{1}$ \\ Akademi Analis Kesehatan Nasional Surakarta \\ Nanik Prihartanti ${ }^{2}$ \\ Fakultas Psikologi Universitas Muhammadiyah Surakarta
}

\begin{abstract}
This research aimed to know the effects of the methods of bibliotherapy and discussion on moral dilemma in enhancing responsible character. The subjects of the research were 65 students of "AN" divided into three groups; bibliotherapy experimental group, moral discussion experimental group and non-treatment control group. The research used pretestposttest-follow-up design. The data of this experimental research were obtained by using scale of responsible character consisting of aspects of self-control skill, risk-taking for personal choice and seriousness of doing obligation to other. The data were then analyzed using SPSS.19 software program. The analysed factors indicated that there were five dimensions shaping students' responsible character, namely carefulness, task oriented, excellence, preseverance and commitment. Based on the hypothesis test through one-way anava technique, it was concluded that the two methods have effect on the enchancement of students' responsible character.
\end{abstract}

Keywords: bibliotherapy, character, moral dilemma, responsibility

\begin{abstract}
Abstrak. Penelitian ini bertujuan untuk mengetahui pengaruh metode biblioterapi dan metode diskusi dilema moral dalam meningkatkan karakter tanggung jawab. Subjek dalam penelitian terdiri dari 65 mahasiswa "AN" yang dibagi dalam tiga kelompok yaitu kelompok eksperimen biblioterapi, kelompok eksperimen diskusi dilema moral, dan kelompok kontrol non perlakuan. Penelitian ini menggunakan rancangan eksperimen nonequivalent pre test-post test control group design. Data pada penelitian diperoleh melalui skala karakter tanggung jawab. Data hasil penelitian dinalisis dengan menggunakan program SPSS.19. Hasil analisis faktor terhadap skala karakter tanggungjawab menunjukkan bahwa skala karakter tanggungjawab memiliki lima faktor yaitu; kehati-hatian, orientasi pada tugas, keunggulan, kegigihan dan komitmen. Berdasarkan uji hipotesis melalui teknik one way anava, diperoleh hasil bahwa metode biblioterapi dan metode diskusi dilema moral berpengaruh terhadap peningkatan karakter tanggung jawab pada mahasiswa.
\end{abstract}

Kata kunci: biblioterapi, dilema moral, karakter, tanggung jawab

Tujuan pendidikan di Indonesia tidak hanya mencerdaskan peserta didik secara kognitif, tetapi juga membentuk peserta didik menjadi manusia yang beradab,

\footnotetext{
${ }^{1}$ Korespondensi mengenai isi artikel ini dapat dilakukan melalui: viana072@gmail.com

22Atau melalui: nanik.prihartanti@ums.ac.id
}

berakhlak mulia dan bertanggung jawab. Tanggung jawab merupakan salah satu karakter penting yang harus dimiliki peserta didik. Menurut Undang-Undang RI Nomor 12 Tahun 2012 pendidikan tinggi memiliki peran penting dalam menyiapkan peserta didik yang akan terjun 
ke dunia kerja dan masyarakat. Clarken (2010) menyatakan terdapat empat aspek yang dapat menunjukkan seseorang memiliki kecerdasan moral yaitu aspek integritas, tanggung jawab, pemaaf, dan memiliki kepedulian pada sesama. Aspek tanggung jawab merupakan aspek utama yang dapat menjadi indikator bahwa orang tersebut memiliki kecerdasan moral yang bagus. Salah satu karakter utama dalam pendidikan karakter mahasiswa di kampus Akademi Analis Kesehatan Nasional Surakarta adalah karakter tanggung jawab. Karakter tanggung jawab penting diajarkan karena mahasiswa berada pada tahap transisi yang akan terjun langsung ke masyarakat dimana pada masa ini mahasiswa juga seharusnya sudah mampu bertanggung jawab atas keputusan atau pilihan yang diambil. Selain itu dilihat dari tugas perkembangan yang harus diselesaikan, menurut Hurlock (2000) mahasiswa berada dalam tahap perkembangan peralihan dari remaja akhir ke dewasa dini yaitu pada usia 18-21 tahun. Pada masa ini remaja dituntut untuk mencapai tugas perkembangan moral yaitu mempelajari apa yang diharapkan oleh kelompok, kemudian membentuk perilakunya agar sesuai dengan harapan sosial yang universal tanpa pengawasan, dorongan, dan ancaman hukuman seperti pada masa kanakkanak.

Sudrajat (2012) mengemukakan bahwa ada empat strategi yang dapat dilakukan untuk mengoptimalkan pendidikan karakter dalam menumbuhkan nilai-nilai moral di lingkungan akademik yaitu meliputi pengajaran (teaching), keteladanan (modeling), penguatan (reinforcing), dan pembiasaan (habituating). Pengajaran yaitu dengan memberikan pengetahuan merupakan tahap pertama yang harus dilakukan dalam upaya membentuk karakter seseorang setelah memperoleh pengajaran baru kemudian dapat diefektifkan dengan keteladanan, penguatan, dan pembiasaan dalam lingkungan kehidupan sehari-hari.

Pendidikan karakter memiliki sejumlah pendekatan dan metode dalam membentuk karakter diantaranya dari dimensi kognitif terdapat tiga pendekatan yang dapat diambil yaitu pendekatan perkembangan moral kognitif, pendekatan analisis nilai, dan pendekatan klarifikasi nilai. Ketiga pendekatan kognitif tersebut dapat diaplikasikan dalam pengajaran dengan menggunakan metode diskusi yang bervariasi dan komunikatif antara dosen dan mahasiswa, salah satunya dapat dilakukan dengan diskusi menggunakan kasus dilema moral. Dimensi afektif dilakukan dengan pendekatan penanaman nilai menggunakan metode pembelajaran reflektif, story telling dan biblioterapi. Dimensi yang ketiga yaitu dimensi psikomotorik menggunakan pendekatan pembelajaran berbuat dengan metode sosiodrama dan role play (Elmubarok, 2006). Dalam penelitian ini peneliti akan menguji dua metode yang dipilih, yaitu metode biblioterapi dan metode diskusi dilema moral. Kedua metode ini akan diuji pengaruhnya dalam peningkatan karakter tanggung jawab. Apakah kedua metode ini dapat meningkatkan karakter tanggung jawab?

Metode biblioterapi dipilih karena dapat mendekatkan individu pada buku dan menjadikan individu terbiasa membaca. Para ahli biblioterapi mengidentifikasi fungsi biblioterapi sebagai suatu pembentukan kehidupan individu melalui pertumbuhan kesadaran. Oleh karena itu biblioterapi bisa diterapkan sebagai salah satu teknik bimbingan untuk pengembangan perilaku moral, biblioterapi mempunyai manfaat sebagai nurturent effect yakni diperolehnya pengetahuan tentang materi bacaan, timbul sikap kritis, dan 
menambah wawasan pembaca melalui penumbuhan kesadaran khususnya moral. Hal ini penting agar individu dapat menyesuaikan diri dengan standar sosial serta ideal yang sesuai dengan nilai dan norma di masyarakat dan diinternalisasi dalam kehidupan (Susanti \& Andriata, 2011).

Metode kedua yang dipilih peneliti sebagai pembanding adalah metode diskusi dilema moral. Berbeda dengan metode biblioterapi yang lebih mengutamakan segi afektif, metode diskusi dilema moral menggunakan pendekatan perkembangan moral kognitif. Metode ini memiliki kelebihan bahwa anak didorong untuk menuju tahap perkembangan moral yang lebih tinggi, mudah diaplikasikan di kelas, dan menghidupkan suasana kelas. Namun demikian metode ini juga memiliki kekurangan bahwa metode ini terlalu mementingkan aspek kognitif dan lebih mengutamakan alasan dibalik pemilihan nilai dibanding benar salahnya nilai yang dipilih (Elmubarok, 2006).

Menurut Roselina dan Shukry (2006) metode biblioterapi dapat digunakan untuk membentuk konsep diri positif, memahami tingkah laku dan motivasi remaja, melegakan tekanan emosi, serta mendiskusikan masalah penyimpangan moral secara terbuka untuk melihat berbagai pilihan dalam penyelesaian masalah. Pernyataan tersebut diperkuat oleh Hidayat (2008) yang mengemukakan bahwa metode biblioterapi dapat digunakan untuk menangani masalah kebingungan remaja terhadap nilai-nilai moral yang bila tidak segera ditangani dapat menyebabkan terjadinya kenakalan remaja. Berdasarkan kedua pendapat tersebut dapat dinyatakan bahwa biblioterapi merupakan salah satu metode yang dapat digunakan untuk mengintervensi moral individu dalam menanamkan nilai-nilai moral positif yang salah satunya tanggung jawab. Menurut Clarken (2010) karakter tanggung jawab merupakan salah satu karakter moral positif yang harus dimiliki individu sebagai indikasi bahwa individu tersebut memiliki inteligensi moral. Selain itu penggunaan metode biblioterapi dapat memberikan beberapa pengaruh seperti membantu individu memahami diri sendiri dan lingkungan, membantu individu membuat alternatif pilihan serta mengambil keputusan dalam pemecahan masalah secara lebih tepat untuk menuntaskan tugas perkembangan dan mewujudkan diri secara optimal (Yuliawati, 2011). Metode biblioterapi dapat diberikan untuk mengintervensi karakter tanggung jawab pada mahasiswa karena dalam karakter tanggung jawab tersebut mahasiswa akan dihadapkan pada risiko atas keputusan yang diambil sedangkan metode biblioterapi sendiri seperti yang dikemukakan di atas dapat membantu individu membuat alternatif pilihan dalam mengambil keputusan terhadap suatu permasalahan.

Metode kedua yang digunakan dalam penelitian ini adalah metode diskusi dilema moral. Veugelers (2000) mengemukakan bahwa salah satu cara yang dapat digunakan untuk mengajarkan nilai dalam pendidikan karakter adalah dengan pendekatan perkembangan moral kognitif dimana dalam diskusi mengenai kasuskasus moral pendidik dapat mengambil peran sebagai partisipan atau non partisipan. Diskusi dilema moral sendiri merupakan salah satu metode diskusi dalam pendekatan perkembangan moral kognitif sehingga dengan mengajak mahasiswa berdiskusi mengenai kasus berdilema moral diharapkan mahasiswa dapat belajar mempertanggung jawabkan pilihan sekaligus kata-kata yang dikemukakannya di hadapan rekan-rekannya dalam diskusi. Pemilihan metode ini juga berdasarkan 
pendapat Lumpkin (2008) yang mengemukakan bahwa tanpa proses diskusi mengenai kasus-kasus berdilema moral perkembangan moral kognitif individu tidak akan berkembang, perubahan perilaku tidak akan pernah terjadi sehingga perilaku moral potensial yang konsisten juga sulit terjadi. Oleh karena itu, pembentukan karakter termasuk salah satunya karakter tanggung jawab dapat dilakukan dengan mengajak mahasiswa berdiskusi mengenai kasus berdilema moral untuk mendorong perkembangan moral kognitif mahasiswa. Pendapat tersebut diperkuat oleh Adisusilo (2012) yang menyatakan bahwa metode diskusi dilema moral memberikan kebebasan kepada mahasiswa untuk berani mengungkapkan nilai yang dimilikinya dimana dalam pengajarannya yang lebih diutamakan bukan pada nilai seperti apa yang dipilih melainkan alasan dalam memilih nilai tersebut. Dengan kata lain, dapat disimpulkan bahwa metode diskusi dilema moral mengajarkan mahasiswa untuk berani berpendapat dengan mempertanggungjawabkan alasan dibalik pendapat yang dikemukakan berdasarkan internalisasi nilai moral dalam dirinya.

Menurut Smith (2007) metode biblioterapi dan diskusi dilema moral dilihat sesuai untuk mengintervensi individu dalam meningkatkan karakter tanggung jawab, yaitu melakukan yang seharusnya dilakukan sebagai kewajibannya, membawa andil positif dalam pekerjaannya, dan menerima konsekuensi dari tindakannya. Dalam metode biblioterapi individu diajak untuk melakukan identifikasi diri terhadap tokoh dalam cerita dan dampak yang diperoleh bilamana berlaku sama seperti tokoh dalam cerita. Demikian halnya pada metode diskusi dilema moral juga mengajarkan untuk menerima konsekuensi pilihan nilai yang diambil dalam diskusi. Hal ini juga sesuai dengan pengertian karakter tanggung jawab yang dikemukakan Samani dan Hariyanto (2011) dalam rancangan pendidikan karakter, yaitu bahwa karakter tanggung jawab adalah melakukan tugas sepenuh hati, bekerja dengan etos kerja yang tinggi, berusaha keras mencapai prestasi terbaik, mampu mengontrol diri dan mengatasi stres, disiplin, serta bertanggung jawab terhadap pilihan dan keputusan yang diambil.

Karakter tanggung jawab, menurut Clarken (2010) harus memenuhi tiga hal yaitu mampu mengendalikan diri, yang artinya memiliki tanggung jawab sebagai pribadi untuk menjalankan tugas semaksimal mungkin; mengakui kesalahan dan kegagalan, yaitu memiliki keberanian menanggung risiko atas kegagalan atau kesalahan dalam mengambil keputusan; dan memiliki kesungguhan dalam melayani orang lain. Demikian halnya dengan yang dikemukakan oleh Zuriah (2007) bahwa karakter tanggung jawab yaitu mengembangkan keseimbangan antara hak dan kewajiban, berani menghadapi konsekuensi dari pilihan hidup dan mengembangkan sikap hidup bermasyarakat yang positif.

\section{Metode}

Penelitian ini menggunakan pendekatan quasi experimental dengan rancangan nonequivallent pre test and post test control group design (Creswell, 2010). Subjek penelitian terdiri dari 65 mahasiswa " $\mathrm{AN}^{\prime}$ Surakarta dengan kriteria: (1) berusia 1821 tahun, (2) belum pernah mengikuti kuliah kepribadian dan pendidikan karakter, dan (3) memiliki skor skala karakter tanggung jawab (KTJ) dalam kategori rendah sampai sedang.

Metode pengumpulan data dilakukan dengan menggunakan angket berupa skala KTJ yang meliputi aspek-aspek; 
memiliki kemampuan untuk mengendalikan diri, berani menanggung risiko atas pilihan, dan memiliki kesungguhan dalam menjalankan kewajiban terhadap orang lain. Penyusunan skala KTJ diawali dengan uji validitas isi oleh expert judgment, dilanjutkan uji validitas kriteria dan terakhir dengan pengujian validitas konstrak melalui analisis faktor. Pemilihan aitem yang valid dilakukan dengan teknik corrected item total correlation. Untuk reliabilitas alat ukur skala KTJ dilakukan dengan menggunakan pendekatan alpha cronbach.

Pada pelaksanaan eksperimen subjek dibagi menjadi tiga kelompok, yaitu kelompok A, kelompok B, dan kelompok C. Kelompok A mendapatkan perlakuan metode biblioterapi (X1), kelompok B mendapatkan perlakuan diskusi dilema moral (X2), sedangkan kelompok $\mathrm{C}$ tidak diberi perlakuan pada saat eksperimen berlangsung. Masing-masing kelompok akan diukur tingkat karakter tanggung jawabnya sebanyak dua kali, melalui pre test (01) dan post test (02). Model rancangan selengkapnya seperti Gambar 1 (Creswell, 2010).

Perlakuan metode biblioterapi diberikan selama tiga sesi, pada setiap sesinya diberikan cerita yang mengandung nilai karakter tanggung jawab sesuai dengan aspek-aspek karakter tanggung jawab. Cerita yang diberikan adalah cerita utuh yang kemudian dibahas bersama antara fasilitator dengan subjek penelitian. Pada setiap akhir sesi, subjek penelitian diminta untuk mengambil pesan moral dari cerita yang diberikan.

\begin{tabular}{llll} 
Kelompok A & 01 & X1 & 02 \\
\hline Kelompok B & 01 & X2 & 02 \\
\hline Kelompok C & 01 & - & 02
\end{tabular}

Gambar 1. Rancangan Eksperimen

\section{Perlakuan diskusi dilema moral}

Perlakuan diskusi dilema moral ini juga diberikan selama tiga sesi. Pada setiap sesi, subjek penelitian diberikan sebuah kasus berdilema moral yang mengandung aspek-aspek karakter tanggung jawab untuk dilakukan diskusi kelompok kemudian masing-masing subjek dengan arahan fasilitator diminta berpendapat mengenai keputusan yang akan diambil dalam menyelesaikan kasus tersebut dengan mempertimbangkan kelebihan dan kekurangannya untuk dapat memilih keputusan yang terbaik. Pada kelompok kontrol, subjek penelitian tidak diberikan perlakuan apapun, namun sebagai kelompok waiting list, akan diberi perlakuan setelah eksperimen selesai

Data dianalisis dengan teknik analisis statistik one way anova terhadap hasil gain skor pre test- post test skala KTJ pada kelompok A, kelompok B dan kelompok C (kelompok kontrol) dengan menggunakan program SPPS.19.

\section{H a s i 1}

\section{Skala Karakter Tanggung jawab}

Hasil uji validitas isi skala KTJ dilakukan dengan teknik corrected item total correlation, diperoleh 20 aitem yang memiliki skor antara 0,258-0,633 dengan angka reliabilitas alpha cronbach sebesar 0,823. Hasil perhitungan analisis faktor menunjukkan nilai KMO 0,847 dengan $p<0,01$ sehingga analisis faktor layak dilakukan. Berdasarkan nilai eigenvalue diperoleh lima faktor penyusun karakter tanggung jawab yaitu kehati-hatian, orientasi tugas, keunggulan, kegigihan, dan komitmen. Kelima faktor tersebut memberikan sumbangan sebesar $66,432 \%$.

Masing-masing faktor skala KTJ memiliki beberapa indikator. Faktor Kehati- 
-... hatian terdiri dari dua indikator yaitu; mempertimbangkan risiko tindakan dan memiliki kemampuan berpikir sebelum bertindak. Faktor Orientasi tugas terdiri dari dua indikator yaitu; penilaian terhadap keberhasilan atau kegagalan dalam menyelesaikan tugas dan menjalankan kewajiban dengan sepenuh hati. Faktor Keunggulan terdiri dari dua indikator yaitu; totalitas dan memberikan yang terbaik. Faktor Kegigihan terdiri dari dua indikator yaitu; pantang menyerah dan berani menerima dampak pilihannya. Faktor Komitmen terdiri dari dua indikator yaitu; kemampuan mempertahankan motivasi dan fokus dalam bertugas. Dengan demikian karakter tanggung jawab dalam penelitian ini diartikan sebagai orang yang memiliki serangkaian karakter seperti; kehati-hatian dalam bertindak, senantiasa berorientasi pada tugas, memiliki keunggulan, kegigihan dan komitmen dalam bertugas (lihat Tabel 1).

Tabel 1

Penamaan Faktor Baru Setelah Analisis Faktor

\begin{tabular}{|c|c|c|c|c|c|}
\hline No & Aitem & F/UF & $\begin{array}{c}\text { Muatan } \\
\text { Faktor }\end{array}$ & Uraian Aitem & Nama Faktor \\
\hline \multirow[t]{9}{*}{1.} & 4 & $\mathrm{~F}$ & 0,705 & $\begin{array}{l}\text { Dalam bertindak, saya lebih mengutamakan } \\
\text { mengikuti kata hati saya }\end{array}$ & Kehati-hatian \\
\hline & 5 & UF & 0,798 & $\begin{array}{l}\text { Keberhasilan saya menyelesaikan tugas dengan } \\
\text { nilai baik lebih karena keberuntungan }\end{array}$ & \\
\hline & 6 & UF & 0,608 & $\begin{array}{l}\text { Saya sering menyesali tindakan yang sudah saya } \\
\text { lakukan di kemudian hari }\end{array}$ & \\
\hline & 13 & UF & 0,775 & $\begin{array}{l}\text { Saya adalah orang yang cepat bertindak } \\
\text { sehingga terkadang kurang memikirkan } \\
\text { dampak tindakan saya }\end{array}$ & \\
\hline & 14 & UF & 0,801 & $\begin{array}{l}\text { Saya merasa takut dan terbebani ketika diminta } \\
\text { menanggung risiko perbuatan saya }\end{array}$ & \\
\hline & 17 & $\mathrm{~F}$ & 0,463 & $\begin{array}{l}\text { Saya merasa jika dalam memutuskan suatu hal } \\
\text { saya harus mempertimbangkan dulu risikonya }\end{array}$ & \\
\hline & 18 & UF & 0,825 & $\begin{array}{l}\text { Dalam mengerjakan tugas, kualitas tidak begitu } \\
\text { penting karena teman -teman juga mengerjakan } \\
\text { seadanya }\end{array}$ & \\
\hline & 19 & UF & 0,819 & $\begin{array}{l}\text { Saya hanya melakukan hal-hal yang bermanfaat } \\
\text { bagi kepentingan pribadi saya }\end{array}$ & \\
\hline & 20 & UF & 0,819 & $\begin{array}{l}\text { Saya melakukan suatu hal dengan memikirkan } \\
\text { dampaknya belakangan }\end{array}$ & \\
\hline \multirow[t]{3}{*}{2.} & 2 & UF & 0,650 & $\begin{array}{l}\text { Kegagalan saya karena patner yang kurang } \\
\text { kooperatif dan lingkungan yang tidak } \\
\text { mendukung }\end{array}$ & $\begin{array}{l}\text { Orientasi pada } \\
\text { tugas }\end{array}$ \\
\hline & 7 & UF & 0,691 & $\begin{array}{l}\text { Ketika melakukan suatu hal, penilaian orang } \\
\text { lain terhadap saya lebih penting daripada } \\
\text { pertimbangan-pertimbangan lain }\end{array}$ & \\
\hline & 8 & $\mathrm{~F}$ & 0,555 & $\begin{array}{l}\text { Saya merasa malu jika kurang berhasil dalam } \\
\text { menyelesaikan tugas }\end{array}$ & \\
\hline
\end{tabular}




\begin{tabular}{|c|c|c|c|c|c|}
\hline No & Aitem & F/UF & $\begin{array}{l}\text { Muatan } \\
\text { Faktor }\end{array}$ & Uraian Aitem & Nama Faktor \\
\hline \multirow{4}{*}{3.} & 9 & $\mathrm{~F}$ & 0,772 & $\begin{array}{l}\text { Saya harus mendapatkan nilai yang bagus untuk } \\
\text { setiap tugas yang berhasil saya selesaikan }\end{array}$ & \multirow{4}{*}{ Keunggulan } \\
\hline & 11 & $\mathrm{~F}$ & 0,534 & $\begin{array}{l}\text { Dalam situasi apapun saya selalu berusaha } \\
\text { menyelesaikan semua kewajiban saya tanpa } \\
\text { terkecuali }\end{array}$ & \\
\hline & 12 & UF & 0,580 & $\begin{array}{l}\text { Ketika saya gagal menyelesaikan tugas dan ada } \\
\text { teman yang senasib maka saya menganggap } \\
\text { kegagalan ini bukan masalah besar }\end{array}$ & \\
\hline & 16 & $\mathrm{~F}$ & 0,828 & $\begin{array}{l}\text { Saya memberikan totalitas kemampuan saya } \\
\text { agar tugas saya terselesaikan dengan baik } \\
\text { sehingga saya mendapat kepercayaan lebih }\end{array}$ & \\
\hline \multirow[t]{2}{*}{4.} & 1 & $\mathrm{~F}$ & 0,602 & $\begin{array}{l}\text { Ketika saya gagal melakukan suatu tugas maka } \\
\text { saya tidak akan menyerah sampai tugas tersebut } \\
\text { berhasil baik }\end{array}$ & \multirow[t]{2}{*}{ Kegigihan } \\
\hline & 3 & $\mathrm{~F}$ & 0,780 & $\begin{array}{l}\text { Jika saya sudah membuat pilihan maka apapun } \\
\text { risikonya saya akan menerimanya }\end{array}$ & \\
\hline \multirow[t]{2}{*}{5.} & 10 & $\mathrm{~F}$ & 0,838 & $\begin{array}{l}\text { Saya merasa termotivasi untuk menanggung } \\
\text { risiko atas pilihan yang saya ambil }\end{array}$ & \multirow[t]{2}{*}{ Komitmen } \\
\hline & 15 & $\mathrm{~F}$ & 0,687 & $\begin{array}{l}\text { Dalam menjalankan tugas, saya selalu } \\
\text { memegang teguh komitmen sehingga saya bisa } \\
\text { fokus menyelesaikan tugas }\end{array}$ & \\
\hline
\end{tabular}

Berdasarkan Tabel 1 terlihat bahwa penyebaran jumlah aitem tiap faktornya tidak sama. Faktor kehati-hatian memiliki jumlah aitem paling banyak (sembilan aitem), menyusul kemudian adalah faktor orientasi pada tugas terdiri dari lima aitem. Selanjutnya untuk faktor keunggulan, faktor kegigihan dan faktor komitmen masing-masing terdiri dari dua aitem.

\section{Hasil analisis Uji Hipotesis}

Uji hipotesis dilakukan dengan menggunakan gain skor pre test dan post test, pada kelompok A, kelompok B, dan kelompok C. Tabel 1 menunjukkan skor rerata tingkat karakter tanggung jawab pada masing-masing kelompok.

Tabel 2 memperlihatkan peningkatan skor paling besar terjadi pada kelompok A, yaitu kelompok yang diberi perlakuan metode biblioterapi, ditunjukkan dengan angka gain skor sebesar -6.91. Hal ini berarti metode biblioterapi lebih besar pengaruhnya dibanding metode diskusi dilema moral. Selanjutnya berdasarkan hasil analisis data dengan teknik one way anava, ditemukan hasil seperti pada Tabel 3.

Tabel 2

Skor Rerata Karakter Tanggunjawab

\begin{tabular}{clccc}
\hline Kelompok & Perlakuan & Rerata Pre Test & Rerata Post Test & Rerata Gain skor \\
\hline A. & Biblioterapi & 62.41 & 69.32 & -6.91 \\
B. & Diskusi & 62.64 & 67.18 & -4.55 \\
& Dilema Moral & & & \\
C. & Tanpa perlakuan & 62.67 & 63.14 & -0.48 \\
\hline
\end{tabular}


Tabel 3

Hasil analisis one way anova karakter tanggungjawab

\begin{tabular}{lccccc}
\hline & Sum of Squares & $d f$ & Mean Square & $F$ & Sig. \\
\hline Between Groups & 453.428 & 2 & 226.714 & 3.158 & .049 \\
Within Groups & 4450.511 & 62 & 71.782 & & \\
\hline \multicolumn{1}{c}{ Total } & 4903.938 & 64 & & & \\
\hline
\end{tabular}

Berdasarkan Tabel 3. dapat dilihat bahwa nilai $F$ hitung 3,158 dengan $p<0,05$. Berarti $\mathrm{Ho}$ ditolak dan $\mathrm{Ha}$ diterima, artinya ada pengaruh metode biblioterapi dan diskusi dilema moral terhadap karakter tanggung jawab. Disimpulkan bahwa hipotesis mayor dan hipotesis minor satu dan dua diterima. Untuk melihat apakah pengaruh perlakuan ini bersifat sementara atau relatif menetap, maka satu minggu kemudian dilakukan pengukuran kembali terhadap kelompok eksperimen sebagai follow up. Data hasil analisis tersaji pada Tabel 4.

Berdasarkan Tabel 4 diperoleh nilai $F$ hitung sebesar 1,306 dengan $p>0.05$ maka dapat dinyatakan bahwa pengaruh perlakuan masih bertahan sampai dengan seminggu setelah eksperimen selesai. Perubahan skor karakter tanggungjawab dari pre test, post test, dan follow up terlihat pada Gambar 2.

\section{Diskusi}

Hasil analisis data menunjukkan bahwa metode biblioterapi dan metode diskusi dilema moral, sama-sama berpe- ngaruh terhadap peningkatan karakter tanggung jawab pada mahasiswa. Metode biblioterapi berfokus pada dimensi afektif, sedangkan metode diskusi dilema moral berfokus pada dimensi kognitif. Menurut Adisusilo (2012) ranah afektif seseorang mengalami perkembangan seperti halnya dalam ranah kognitif. Pendidikan dapat merupakan salah satu wahana yang dapat membantu perkembangan ranah afektif dan kognitif peserta didik. Matarazzo, Abbamonte, dan Nigro (2008) menjelaskan bahwa komponen kognitif dan afektif seseorang merupakan faktor yang ikut menentukan pertimbangan moral dan perilaku moral seseorang. Sejalan dengan pendapat Adisusilo (2012), dan Matarazzo, dkk. (2008), hasil penelitian ini menunjukkan bahwa pendidikan melalui metode biblioterapi dan diskusi dilema moral mampu mengembangkan karakter tanggung jawab. Dalam konteks ini, pengembangan ranah afeksi difasilitasi melalui metode biblioterapi, sedangkan pengembangan ranah kognitif difasilitasi melalui metode diskusi dilema moral. Temuan penelitian ini sekaligus menguatkan pendapat Floyd (2004) yang menjelaskan bahwa modifikasi perilaku untuk menginter-

Tabel 4

Hasil uji beda post test follow up skor karakter tanggungjawab

\begin{tabular}{lccccc}
\hline & Sum of Squares & $d f$ & Mean Square & F & Sig. \\
\hline Between Groups & 23.273 & 1 & 23.273 & 1.306 & .260 \\
Within Groups & 748.273 & 42 & 17.816 & & \\
\hline Total & 771.545 & 43 & & & \\
\hline
\end{tabular}




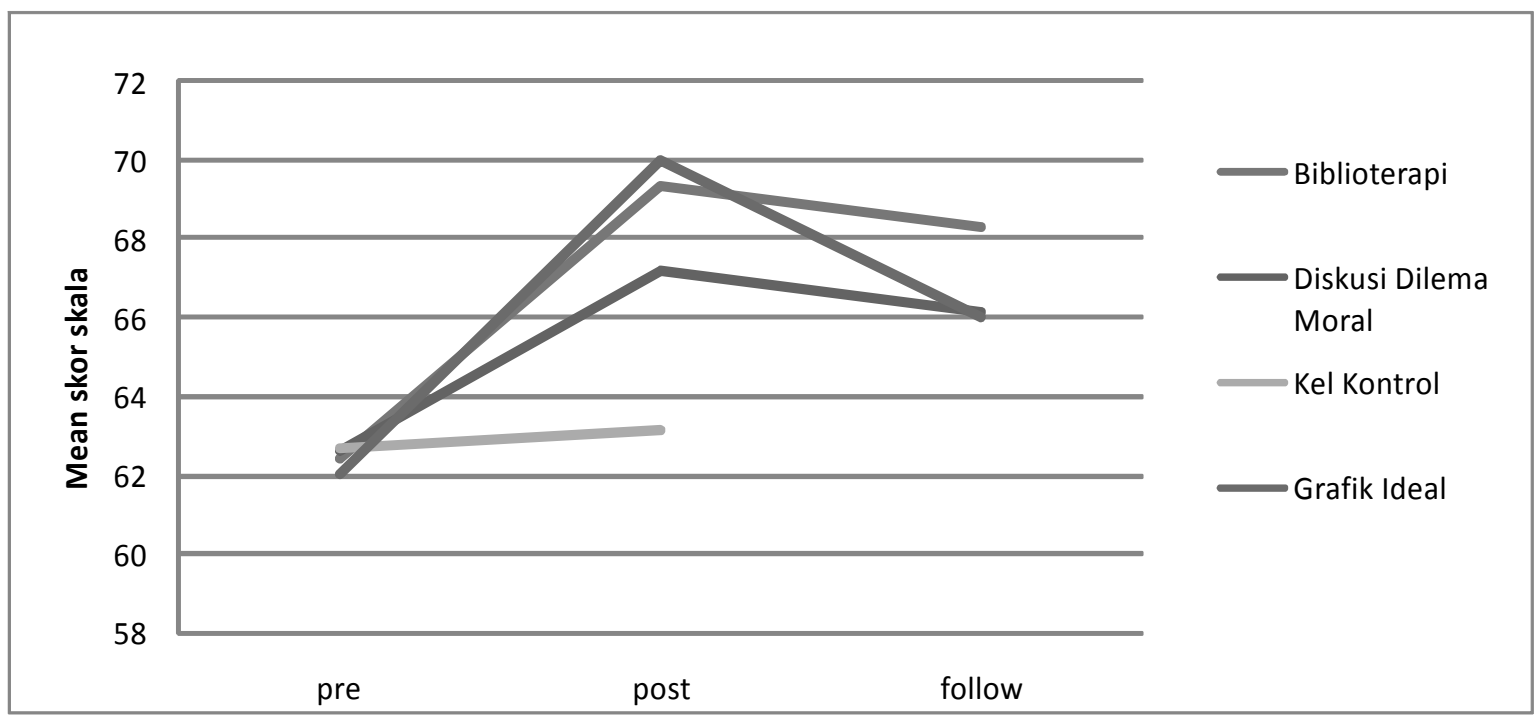

Gambar 2. Grafik Skor Tanggungjawab

vensi perilaku seseorang dapat dilakukan dengan tiga cara yaitu biblioterapi, psikoterapi kognitif individu, dan treatment tertunda. Menurut Ready (2002) cerita dalam biblioterapi dapat memberikan dampak yang efektif karena biblioterapi memiliki isi cerita yang spesifik, tingkat atau kadar yang sesuai karakteristik subjek, diberikan oleh guru/role model yang dihormati siswa, cerita yang diberikan memiliki kesan drama (berkesan), serta memiliki kandungan nilai belajar yang tinggi sehingga mampu menjadi salah satu bentuk intervensi psikologis yang memiliki kekuatan mengubah.

Biblioterapi merupakan aplikasi langsung dari metode membaca untuk mempengaruhi perubahan dalam karakter/ perilaku seseorang. Hal ini didasarkan pada asumsi bahwa terdapat kesamaan yang kuat antara karakter tokoh cerita dalam buku dengan pembaca memungkinkan menjadi role model, yang dapat memiliki efek kuratif. Membaca dapat mempengaruhi perilaku baik atau jahat dan sangat mungkin untuk menanamkan prinsip-prinsip baik maupun buruk melalui kegiatan membaca (Smith, 1948). Menurut Lodge (1956) muatan nilai yang terbungkus dalam karya sastra mampu mempengaruhi perkembangan moral dan karakter seseorang terutama pada masa remaja. Biblioterapi berpengaruh untuk membentuk moral dan karakter remaja sebagai sarana belajar etika, mengidentifikasikan diri, bimbingan dalam memperluas konsep tentang nilai pribadi sehingga memunculkan figur ideal.

Biblioterapi adalah proses dinamis yang merupakan interaksi antara buku dengan pembaca, proses tersebut bermanfaat untuk asesmen, penyesuaian, dan pertumbuhan kepribadian. Penggunaan teknik ini dalam kelas dapat sebagai tindakan terapi maupun preventif (Olsen, 1975). Menurut Maich dan Kean (2004) suatu intervensi psikologis dengan metode biblioterapi menjadi bernilai karena pesan moral yang terkandung dalam cerita dapat berpengaruh secara positif di dalam pikiran tidak sadar individu bahkan meskipun pikiran tidak sadar tersebut sedang tidak aktif dalam memproses informasi (pesan moral). Sehingga kesan yang dihasilkan akan terekam dalam waktu yang relatif lama.

Hasil penelitian ini memperkuat temuan penelitian Sweeney (2008) yang mengemukakan bahwa penggunaan cerita 
untuk mengajarkan karakter menunjukkan peningkatan yang signifikan dalam pemahaman siswa terhadap konsep karakter baru apabila memenuhi syarat sebagai berikut: setelah diberikan suatu cerita bermuatan nilai karakter tertentu kemudian guru mengajak diskusi dan sharing secara efektif sehingga siswa mampu memahami dan mengambil hikmah dari cerita yang diberikan, sebelum cerita diberikan terlebih dahulu dibuat modul yang berfungsi sebagai alat untuk memperkuat ide-ide dari cerita yang diberikan, kemampuan guru memilih cerita yang bernilai sebagai pendektan dalam pengajaran, dan kemampuan guru memilih cerita yang dapat masuk ke semua kalangan jika siswanya berasal dari latar belakang yang heterogen. Menurut Malaouff, dkk. (2010) biblioterapi dapat digunakan dengan atau tanpa peran dan dukungan terapis. Media buku sebagai cara untuk membantu diri sendiri tanpa bantuan terapis dalam mengurangi tingkat stres karena biblioterapi dapat menjadi sarana pengobatan psikis yang murah yang tidak terikat oleh waktu dan tempat.

Penggunaan metode biblioterapi sendiri memiliki memiliki nurturent effects yaitu mendekatkan mahasiswa pada buku dimana pada era digital ini mahasiswa cenderung lebih dekat pada gadget dibanding buku dalam bentuk cetak. Menurut Mangen, Walgermo, dan Bronnick (2013) siswa yang lebih sering membaca pada layar digital memiliki kemampuan memahami bacaan yang lebih rendah dibanding siswa yang lebih sering membaca teks dalam bentuk cetak sehingga temuan ini memiliki implikasi pedagogis yang harus dipertimbangkan untuk memaksimalkan kinerja otak pada siswa. Berdasarkan penelitian yang dilakukan oleh Buchweitz, Manson, Tomitch, dan Just (2009) pembaca yang baik maka juga pasti pendengar yang baik, gabungan antara keduanya akan memberikan hasil yang efektif karena informasi yang terkumpul lebih banyak sehingga dapat dengan mudah diasosiasikan satu dengan yang lain untuk mendapatkan info yang lengkap. Selain itu membaca buku cetak juga memiliki dampak positif seperti yang dikemukakan Cunningham dan Stanovich (2001) yang menyatakan bahwa membaca buku teks cetak akan memberikan pengaruh yaitu mengembangkan kosakata lebih luas dibanding melihat televisi dan mendengarkan ceramah, selain itu semakin pembaca meningkatkan volume membaca maka akan semakin kaya kosakata. Hal ini diperkuat oleh Odwan (2012) yang mengemukakan bahwa sering membaca buku teks dapat meningkatkan pemahaman dan daya konsentrasi.

Hipotesis minor dua pada penelitian ini yang menyatakan bahwa ada pengaruh metode diskusi dilema moral terhadap karakter tanggung jawab pada mahasiswa juga diterima. Hal ini dikarenakan metode diskusi dilema moral dalam pelaksanaannya memiliki empat unsur penting yaitu fokus kasus, mampu melakukan pilihan tindakan, kaitan dengan nilai atau isu moral dan keputusan mengenai apa yang akan dilakukan dalam suatu kondisi dilematis. Setelah melakukan diskusi dilema moral maka mahasiswa akan mengalami peningkatan pemahaman dan perkembangan dalam mengambil keputusan, peningkatan diskusi masalah etika dalam kelas, peningkatan keterampilan komunikasi serta yang tidak kalah pentingnya adalah peningkatan keterampilan dan pengetahuan dalam membuat pilihan hidup yang lebih baik untuk kemudian menyadari dimensi etika dan implikasi dari pilihan yang dibuat (Berkowitz, Higgins, \& Power, 2005). Sehingga dengan berkembangnya sejumlah kemampuan 
baru tersebut mahasiswa menjadi lebih bertanggung jawab dalam bertindak dan mengambil keputusan.

Settlemaier (2004) mengemukakan bahwa dalam menggunakan metode dilema moral untuk mengajarkan nilai dan membentuk karakter, pengajar harus mempertimbangkan tujuh kemampuan pedagogis berikut ini yaitu kesesuaian cerita atau kasus berdilema moral, keaslian refleksi individu, wacana moral, frekuensi dilema, kemampuan guru mengajak siswa berpendapat, perencanaan waktu, dan kemampuan mengatasi siswa bermasalah di kelas. Ketujuh kemampuan pedagogis tersebut cukup terpenuhi selama proses pemberian perlakuan diskusi dilema moral dalam penelitian ini sehingga metode diskusi dilema moral dapat meningkatkan karakter tanggung jawab.

\section{Kesimpulan}

Karakter tanggungjawab dapat dikembangkan baik melalui metode biblioterapi maupun metode diskusi dilema moral. Dalam hal ini, metode biblioterapi memiliki pengaruh yang lebih besar dibanding metode diskusi dilema moral. Mempertimbangkan bahwa muatan karakter cerita dalam bacaan pada metode biblioterapi memiliki pengaruh dalam pembentukan karakter pembaca, maka gerakan budaya membaca dapat menjadi salah satu alternatif untuk mengembangkan karakter mahasiswa. Perlu dipilih bacaan-bacaan yang muatannya relevan untuk pengembangan karakter tanggung jawab mahasiswa. Selain karakter tanggung jawab, terbuka pula kemungkinan untuk diaplikasikan pada karakter lain, seperti kedisiplinan, kejujuran, dan toleransi.

\section{Kepustakaan}

Adisusilo, S. (2012). Pembelajaran Nilai Karakter: Konstruktivisme dan VCT sebagai Inovasi Pendekatan Pembelajaran Afektif. Jakarta: PT Raja Grafindo Persada

Berkowitz, M. W., Higgins, A., \& Power, F. C. (2005). Leading Values and Moral Dilemma Discussions. Missouri: St. Louis University Press

Buchweitz, A., Manson, R., Tomitch, L., Just, M. (2009). Brain Activation for Reading and Listening Comprehension: An fMRI Study of Modality Effects and Individual Differences in Language Comprehension. Journal of Psychology and Neuroscience, 2(2), 111123 doi: 10.3922/j.psns.1009.2.003

Clarken, R. (2010). Considering Moral Intelligence. As Part of A Holistic Education. Denver: Northern Michigan University

Creswell, J. W. (2010). Research Design. Pendekatan Kualitatif, Kuantitatif, dan Mixed. Yogyakarta: Pustaka Pelajar

Cunningham, A., \& Stanovich, K. (2001). What Reading Does for The Mind. Journal of Direct Instruction, 1(2), 137149.

Elmubarok, Z. (2008). Membumikan Pendidikan Nilai Mengumpulkan yang Terserak, Menyambung yang Terputus, dan Menyatukan yang Tercerai. Bandung: Alfabeta

Floyd, M., Scogin, F., Smith, N., Floyd, D., \& Rokke, P. (2004). Cognitive Therapy for Depression: A Comparison of Individual Psychotherapy and Bibliotherapy for Depressed Older Adults. Journal of Behavior Modification, 28(2), 297-318. 
Hidayat, M. Y. (2008). Aplikasi Bibliokonseling Sebagai Salah Satu Strategi Membantu Klien Dalam Konseling. Jurnal Lentera Pendidikan, 11(1), 129140.

Hurlock, E. (2000). Psikologi Perkembangan: Suatu Pendekatan Sepanjang Rentang Kehidupan. Terjemahan (Edisi Kelima). Jakarta: Erlangga

Lodge, H. (1956). The Influence of The Study of Biography on The Moral Ideology of The Adolescent at The Eight Grade Level. The Journal of Education Research, 50(4), 241-255.

Lumpkin, A. (2008). Teachers as Role Models Teaching Character and Moral Virtues. Joperd, 79(2), 91-98.

Maich, K., \& Kean, S. (2004). Read Two Books and Write Me In The Morning! Bibliotherapy for Social Emotional Intervension in The Inclusive Classroom. Teaching Exceptional Children, $1(2), 5-11$.

Malouff, J., Noble, W., Schutte, N., \& Bhullar, N. (2010). The Effectiveness of Bibliotherapy in Alleviating TinnitusRelated Distress. Journal of Psychosomatic Research, (10)68, 245-251.

Mangen, A., Walgermo, B; Bronnick. (2013). Reading Linear Texts on Papper Versus Computer Screen: Effects of Reading Comprehension. International Journal of Educational Research, 5(58), 61-68. doi:10/1016/ j.ijer.2012.12.002

Matarazzo, O., Abbamonte, L., \& Nigro, G. (2008). Moral Reasoning and Behaviour in Adulthood. International Journal of Human and Social Sciences, 3(3), 199-206.

Odwan, T.A. (2012). The Effect of The Directed Reading Thinking Activity Through Cooperative Learning on English Secondary Stage Students
Reading Comprehension in Jordan. International Journal of Humanities and Social Science, 2(16), 138-151.

Olsen, H. (1975). Bibliotherapy to Help Children Solve Problems. The Elementary School Journal. 75(7), 422-429.

Ready, D. A. (2002). How Story Telling Builds Next Generation Leaders. Massachusetts: EBSCO Publishing

Roselina \& Shukry, M. (2006). Bibliotherapy: A Tool For Primary Prevention Program With Children and Adolescents. Jurnal Antidadah Malaysia, 1(1), 75-90.

Samani, M., \& Hariyanto. (2011). Konsep dan Model Pendidikan Karakter. Bandung: Rosdakarya

Settelmaier, E. (2004). Exploring The Suitability of Dilema Stories as A Way of Addressing Ethical Issues in Science Education. Melbourne: Australian Association for Research in Education

Smith, N. (1948). The Personal and Social Values of Reading. Journal of Elementary English, 25(8), 490-500.

Smith, C. B. (2002). Developing Character Though Literature. Bloomington: Indiana University

Sudrajat. (2012). Mengapa Pendidikan Karakter? Yogyakarta: UNY Press

Susanti, R., \& Andriata, A. (2011). Aplikasi Teknik Bimbingan Pengembangan Perilaku Moral. Diunduh dari: http:// kampusbagus.com/master.php?badan _hukum=99\&jenjang=2\&school=1033\& major=86201 tangal 8 Desember 2012.

Sweeney, L. (2008). The Case For Character Education. Sydney: Marsh Media White Paper

Veugelers, W. (2000). Different Ways of Teaching Values. Educational Review, 52, 95-103. 
Yuliawati, R. (2011). Layanan Bimbingan dan Konseling Berbasis Biblioterapi: sebuah Upaya Pengembangan Perpustakaan Sekolah. Visi Pustaka, 13(7), 1924.

Undang-Undang Republik Indonesia No. 12 Tahun 2012 Tentang Pendidikan Tinggi
Undang-Undang Republik Indonesia No. 20 Tahun 2003 Tentang Sistem Pendidikan Nasional

Zuriah, N. (2007). Pendidikan Moral dan Budi Pekerti dalam Perspektif Perubahan. Jakarta: Bumi Aksara. 